\title{
Growth Performance of Fresh Water Microalgae Chlorella sp. Exposed to Carbon Dioxide
}

\author{
Titin Handayani, Adi Mulyanto, and Fajar Eko Priyanto
}

\begin{abstract}
It is generally recognized, that algae could be an interesting option for reducing $\mathrm{CO}_{2}$ emissions. Based on light and $\mathrm{CO}_{2}$, algae can be used for the production various economically interesting products. Current algae cultivation techniques, however, still present a number of limitations. Efficient feeding of $\mathrm{CO}_{2}$, especially on a large scale, is one of them. Current methods for $\mathrm{CO}_{2}$ feeding to algae cultures rely on the sparging pure $\mathrm{CO}_{2}$ or directly from flue gas. The limiting factor in this system is the solubility of $\mathrm{CO}_{2}$ in water, which demands a considerable amount of energy for an effective gas to liquid transfer and leads to losses to the atmosphere. Due to the current ineffective methods for $\mathrm{CO}_{2}$ introduction into algae ponds very large surface areas would be required for enough ponds to capture a considerable amount of the $\mathrm{CO}_{2}$. The purpose of this study is to assess technology to capture carbon dioxide $\left(\mathrm{CO}_{2}\right)$ emissions generated by industry by utilizing of microalgae Chlorella sp. The microalgae were cultivated in a bioreactor culture pond raceway type. The result is expected to be useful in mitigating the effects of greenhouse gases in reducing the $\mathrm{CO}_{2}$ emissions. The research activities include: (1) Characterization of boiler flue gas, (2) Operation of culture pond, (3) Sampling and sample analysis. The results of this study showed that, the initial assessment absorption of the flue gas by microalgae using $1000 \mathrm{~L}$ raceway pond completed by heat exchanger were quite promising. The transfer of $\mathrm{CO}_{2}$ into the pond culture system was run well. This identified from the success of cooling the boiler flue gas from the temperature of about $200{ }^{\circ} \mathrm{C}$ to below ambient temperature. Except for the temperature, the gas bubbles into the culture media were quite fine. Therefore, the contact between the gas and the media was well performed. Efficiency of $\mathrm{CO}_{2}$ absorption by Chlorella sp reached $6.68 \%$ with average $\mathrm{CO}_{2}$ loading of $0.29 \mathrm{~g} / \mathrm{L} / \mathrm{day}$.
\end{abstract}

Index Terms-Chlorella sp., $\mathrm{CO}_{2}$ emission, heat exchange, microalgae, milk industry, raceway pond.

\section{INTRODUCTION}

Global warming is a phenomenon of global temperature increase from year to year due to the greenhouse effect caused by increased emissions of gases such as carbon dioxide $\left(\mathrm{CO}_{2}\right)$, methane $\left(\mathrm{CH}_{4}\right)$, dinitrooxida $\left(\mathrm{N}_{2} \mathrm{O}\right)$ and $\mathrm{CFC}$, so that solar energy trapped in the earth's atmosphere.

Increasing the amount of greenhouse gas emissions (GHG) in the atmosphere caused by human activities in various sectors, including energy. The use of fossil fuels such as oil, coal and natural gas in a variety of activities, for example in power generation, transportation and industry, will lead to the increasing amount of GHG emissions in the atmosphere.

Manuscript received June 21, 2017; revised October 3, 2017

The authors are with Institute for Environmental Technology, Agency for the Assessment and Application of Technology, BPPT Build. II 12th Floor, MH Thamrin Street No. 8 Jakarta 10340, Indonesia (e-mail: htitin2557@gmail.com, adimu12004@yahoo.com, jarko1186@gmail.com).
Although both produce GHG emissions, but the emissions resulting from the use of three types of fossil fuels is different. To produce $1 \mathrm{kWh}$ of energy, power plants using coal emit about 940 grams of $\mathrm{CO}_{2}$. While power plants that use petroleum and natural gas, resulting in the emission of approximately 798 and 581 grams of $\mathrm{CO}_{2}$ [1].

Several alternatives have been studied in order to promote the reduction of emissions, sequestration and biological fixation of carbon dioxide emitted by stationary sources. One of them is the use of reforestation of photosynthetic organism with the capacity to absorb carbon dioxide from the atmosphere [2], but currently the alternative that has been more studied is the cultivation of microalgae. Microalgae are the main responsible for the biological uptake of atmospheric $\mathrm{CO}_{2}$ in the oceans that cover $3 / 4$ of the globe surface, once that they are present in large numbers in the water column [3]. A portion of the $\mathrm{CO}_{2}$ absorbed by microalgae is transferred to the deep ocean in a process known as "biological pump" [4]. This process, along with direct diffusion of $\mathrm{CO}_{2}$ into the water, prevents that the buildup of "greenhouse effect" gases became even greater. Besides having the capacity to fix carbon dioxide from air, using it as a carbon source, microalgae have the capacity of cycling the organic matter and may offer during its growth a number of mineral elements, vitamins, lipids, pigments and proteins, presenting thus large industrial and commercial applicability [5].

Along with the increasing concentration of anthropogenic $\mathrm{CO}_{2}$ in the atmosphere, a wide range of engineering effort has been made to capture and bury the atmospheric $\mathrm{CO}_{2}$ through carbon capture and storage technology (CCS) from emission sources. One of the CCS technology that allows it to be applied in Indonesia is biosequestration, that capture and store atmospheric $\mathrm{CO}_{2}$ by increasing the volume and quality of photosynthesis through microalgae bioreactor. Currently, experiments regarding the ability of microalgae to absorb $\mathrm{CO}_{2}$ has been done to scale laboratory at the Agency for Assessment and Application of Technology (BPPT) to build a photobioreactor and microalgae culture ponds. The results showed that the absorption of $\mathrm{CO}_{2}$ by microalgae Chlorella sp. can achieve more than $70 \%$, the results are quite promising for the application in order to reduce $\mathrm{CO}_{2}$ emissions from industry. To that end, there should be further engineered into account various important aspects that exist in the industry that technology is feasible biosequestration applies for a period of 1 to 2 years in order to support government action plan reduce $26 \%$ GHG emissions by 2020.

Raceway pond bioreactor given gear pedal/propeller for stirring process, driving electromotor, $\mathrm{CO}_{2}$ gas intake pipe and pipe freshwater and nutrient intake. Pond is made of stainless steel allows the microalgae to absorb light and $\mathrm{CO}_{2}$ 
on the surface to a depth at a certain limit [6]. The culture that is on the inside of the reactor and not get the light can be improved productivity through stirring [7]. In order for the whole microalgae cells in culture ponds can equally get light and absorb $\mathrm{CO}_{2}$, thus increasing productivity, it is equipped with a stirring system. In this study used the pedal stirring system and circulation pump. Temperature carbon emissions come from industry above $100^{\circ} \mathrm{C}$, for it needed a tool to convert temperature into ambient temperature for growth of microalgae.

The aim of this research is to apply technology of capture $\mathrm{CO}_{2}$ emissions generated by industries that use combustion systems by utilizing microalgae Chlorella sp. are cultivated in a bioreactor culture pond raceway types.

\section{MATERIALS AND MethodS}

The research was carried out in milk processing industry (PT Indolakto) located in Sukabumi, West Java, Indonesia. Analysis of samples carried out in the Laboratory of Chemistry and Ecotoxicology Laboratory of Environmental Technology. GEOSTECH building 820, Puspiptek, Serpong.

\section{A. Microalgae Collection, Isolation and Identification}

Microalgae used in this study were collected using a phytoplankton net ( $20 \mu \mathrm{m}$ mesh opening), in a mesocosmos located in the institute fresh water pond. After collection they were taken to the laboratory for isolation and culture.

For the microalgae isolation were utilized excavated blades with the aid of a stereoscope microscope, where the cells were isolated one by one by using glass capillary needles, being subsequently inserted and maintained in test tubes ( $5 \mathrm{ml}$ ) containing synthetic cultivation medium. After isolation, consecutive samplings of the biological material were carried out until achieve the complete purification of microalgae.

In parallel, the identification of the isolated microalgae was performed in test tubes using appropriate laminas and laminules with the assistance of a binocular optical microscope, according to morphological and morphometric characteristics for analysis achieved at the lowest possible taxonomic level based on literature [8]. These cultures were kept in BOD incubator in synthetic medium at $25^{\circ} \mathrm{C}, 1 \mathrm{klux}$ light, $12 \mathrm{~h}$ photoperiod and constant stirring.

\section{B. Bioreactor Culture Ponds}

Bioreactor culture ponds raceway type are ponds that were equipped with pedals/propeller for stirring process, driving electromotor, $\mathrm{CO}_{2}$ gas intake pipe and pipe freshwater and nutrient intake. Microalgae culture ponds are made of stainless steel with a volume of 1,000 liters, the depth of water in the pool can be set $20 \mathrm{~cm}, 15 \mathrm{~cm}$, and $10 \mathrm{~cm}$. The depth of water used in the experiment have been $20 \mathrm{~cm}$. Raceway ponds was equipped with a transparent lid made of plastic (mica) to minimize the risk of contamination of the culture of microalgae. The water used was fresh water.

\section{Inoculation of Microalgae}

Species of microalgae was used Chlorella sp. which has been cultivated in the medium Benneck and then cultured in an acclimatized before advance by using a medium containing NPK $35 \mathrm{mg} / \mathrm{L}$ which would then be used in pond culture systems. Initial density used about 300,000 cells/ml, calculated microscopically using haemocytometer.

The next activity was upscalling gradually from laboratory scale to larger scale. Larger scale carried out in plastic bags volume of 20 liters, equipped aeration. The medium used for the multiplication of the microalgae was water contain 35 $\mathrm{mg} / \mathrm{L}$ NPK fertilizer. The abundance of culture can reach approximately $6 \times 10^{6}$ cells $/ \mathrm{ml}$ of medium after 3-4 weeks that was the level of the density can be transferred to the pond culture volume of 1,000 L.

The pond was filled with water as much as $950 \mathrm{~L}$ who previously had undergone a process of filtration using ultra filtration process to minimize the contamination of the culture of microalgae. Then put microalgae cultures into pond culture as much as 50 liters, until the initial density of 300,000 cells $/ \mathrm{ml}$. The next step was the application of fertilizer $35 \mathrm{mg} / \mathrm{L}$ NPK for the growth of microalgae. Microalgae began to be treated by $\mathrm{CO}_{2}$ emissions in the culture pond after 3 weeks of culture,.

\section{Operation of $\mathrm{CO}_{2}$ Emissions into the Pond}

Microalgae are heterotrophic micro-organisms that resemble plants, thus requiring light and $\mathrm{CO}_{2}$ in addition to nutrients. Determination of $\mathrm{CO}_{2}$ intake is based on the concentration of the gas being sampled from the output (effluent) boiler chimney.

Supplies to distribute $\mathrm{CO}_{2}$ into the pond was such that the gas supply was placed in the gas holder was made of plastic. $\mathrm{CO}_{2}$ in a plastic bag was conditioned with a concentration of about $6 \%$. Another device was the gas piping from plastic bags to pond culture. To suck $\mathrm{CO}_{2}$, used compressors. Gas relief valve installed in the effluent gas,. The exit gas were sampled to measure its $\mathrm{CO}_{2}$ levels.

\section{E. Data Sampling}

In the culture ponds already available pipe/port to perform sampling gases released by the system. Port was located on the side of the upper pond, $1 / 2$ inch diameter. Sampling was done 2 times a day, at around $09.00 \mathrm{am}, 12.00 \mathrm{pm}$ and 15.00 pm. Parameters were the concentration of oxygen and carbon dioxide gas. Equipment used in the form of portable multi-gas detector brands Riken type RX-515. Temperature measurement was carried out around the pond culture and implementation of measurements are made every day at around 9:00 am, $12.00 \mathrm{pm}$ and $15.00 \mathrm{pm}$.

Light intensity affects the activity of microalgae, particularly in terms of photosynthesis. The tool used is a digital instrument Light Meter LX-101A models. Implementation of measurements carried out every day at around $9.00 \mathrm{am}, 12.00 \mathrm{pm}$ and $15.00 \mathrm{pm}$.

The growth of microalgae as a result of the response to $\mathrm{CO}_{2}$ emissions observed by microscopic every day of the number of cells per millimeter using haemocytometer.

\section{RESULTS AND DISCUSSION}

PT. Indolakto, Sukabumi using three (3) boilers are fired 'heavy oil'. This fuel must be stored at a temperature of about $38^{\circ} \mathrm{C}$ and at the time would have to be heated further pumped 
between the temperature of $66^{\circ} \mathrm{C}-121^{\circ} \mathrm{C}$. Each boiler with a capacity of 5 tons of steam per hour. In operation every day, PT. Indolakto using two (2) pieces of the boiler, while the other is in stand-by position. The operating pressure of the boiler reaches 8 bar. The flue gas temperature reaches $230{ }^{\circ} \mathrm{C}$. Exhaust gas discharged through the chimney (towers) as high as approximately 10 meters.

To study the utilization of $\mathrm{CO}_{2}$ from flue boiler conducted in PT. Indolakto, Cicurug, not done desulfurization process. That was because the PT. Indolakto use gas from the State Gas Company. According to PGN, the gas has a calorific value of $900-1300 \mathrm{BTU} / \mathrm{SCF}$ or $7703-11127 \mathrm{Kcal} / \mathrm{m}^{3}$.

Before performing the assembly and installation of pond culture, prior to design a series of studies. After design was done, then done the manufacturing units of operations required to perform research utilization and absorption of $\mathrm{CO}_{2}$ using microalgae culture. Emissions from the boiler has high temperature, which is about $210{ }^{\circ} \mathrm{C}$. The series of processes added were: piping, compressor and scrubber for particulate and SOx absorbing, heat exchangers, cooling pools, and condensate reservoir.

Exhaust gas piping by inserting the tip of a catheter into the chimney was made to resemble a funnel. So that the gas flow occurs, then used a modified compressor. Modifications made were utilizing the intake air inlet as $\mathrm{CO}_{2}$ gas inlet. The gas then flows through a process of absorption of the content of particulates and sulfur compounds and accommodated in the gas bag equalization. In the gas bag is made of gas quality measurement. When it reached the desired quality of the gas by using an aerator, gas flowed into the gas reservoir was ready to put in a pond culture. Gas flows from the bottom of the pond through a distributor (sparger), amounting to 6 pieces.

The system of gas from the gas reservoir into an organized culture using a timer. An aerator was used to transport the gas into the pond culture. An agitation process (using the pedal) and the introduction of gas into the pond done simultaneously and regulated by a timer. With such a system, the gas flow will be in contact with the culture medium in a longer time.

\section{A. Cultivation of Microalgae}

The observation of microalgae Chlorella sp. initially showed poor growth response to seem yellowish green color. The results of the nutritional content analysis of the media showed deficiencies $\mathrm{P}$. After the addition of $\mathrm{P}$ was contained in the fertilizer NPK $(16: 16: 16)$ as much as $35 \mathrm{mg} / \mathrm{l}$, the microalgae color turns to green, fresh and seemed to occur growth. The addition of nutrients to the growth of microalgae are needed every 7 days and the addition of $\mathrm{P}$ is required every 14 days. Graph microalgal growth in period I and II are presented in Fig. 1 and Fig. 2. It shows that the culture pond environment has supported the growth of microalgae. Microalgae Chlorella sp able to absorb $\mathrm{CO}_{2}$ by $15-20 \%$ concentration [9], [10]. Microalgae Chlorella sp is a cosmopolitan microalgae who mostly live in aquatic environments both freshwater, marine and brackish which contains many nutrients, are also found in the soil and in a humid place. Cell Chlorella sp. have a high reproductive rate, each cell Chlorella sp. capable of developing into 10,000 cells within 24 hours [7].

\section{B. Analysis and Interpretation of Culture Pond Performance}

Gas is sucked from the boiler chimney using piping (galvanized) $1 / 2$ inch diameter. Gas discharge into the pond is about 2,091 $\mathrm{L} / \mathrm{min}$. The average concentration of $\mathrm{CO}_{2}$ that goes into the pond is $5.2-5.9 \%$. By setting a timer, then made a two-stage intake amount of gas that goes into a pond that each value of $0.21 \mathrm{~g} / \mathrm{L} /$ day in the first period and $0.3 \mathrm{~g} / \mathrm{L} /$ day in the second period. Conditions of gas into the pond can be seen in Table 1. It can be calculated that the $\mathrm{CO}_{2}$ absorption efficiency $96.90 \%$ for the first period (days 1-30) (Fig. 1) and 98.87\% for the second period (days 1-49) (Fig. 2).

Raising Chlorella sp. culture depends on the match between the types of microalgae are cultivated and some environmental factors, one thing to note is that the mixing factor does not interfere with the metabolism of microalgae cells [11].

Utilization of microalgae culture in the industry for the absorption of $\mathrm{CO}_{2}$ emissions is necessary to control the photobioreactor. Efforts to use algae as a carbon sink requires knowledge about the types of suitable and optimum environmental conditions to encourage maximum growth [12], [13].

\begin{tabular}{|c|c|c|c|c|c|c|}
\hline \multicolumn{1}{|c|}{ TABLE I: THE AVERAGE CAPACITY OF $\mathrm{CO}_{2}$ ABSORPTION } \\
\hline \multirow{2}{*}{ Period } & $\begin{array}{c}\mathbf{C O}_{2} \\
\text { Input }\end{array}$ & $\begin{array}{c}\mathbf{C O}_{2} \\
\text { Output }\end{array}$ & \multicolumn{3}{|c|}{$\mathbf{C O}_{2}$ Absorption } & $\begin{array}{c}\text { Biomassa } \\
\text { (max) }\end{array}$ \\
\cline { 2 - 7 } & $\begin{array}{c}\mathrm{CO}_{2} \\
\text { Consen } \\
\text { tration } \\
(\% \text { vol })\end{array}$ & $\begin{array}{c}\mathrm{CO}_{2} \\
\text { Consen } \\
\text { tration } \\
(\% \text { vol })\end{array}$ & $\begin{array}{c}\mathrm{CO}_{2} \\
\begin{array}{c}\text { Consen } \\
\text { tration } \\
(\% \text { vol })\end{array}\end{array}$ & g/L/day & $\begin{array}{c}\text { Effici } \\
\text { ency } \\
(\%)\end{array}$ & $\begin{array}{c}\mathrm{x} 10^{5} \\
(\mathrm{cell} / \mathrm{ml})\end{array}$ \\
\hline $\begin{array}{c}\text { I } \\
\text { Days } \\
1-30\end{array}$ & 5.2 & 0.3 & 6.11 & 0.21 & 96.90 & 156.2 \\
\hline $\begin{array}{c}\text { II } \\
\text { Days } \\
1-49\end{array}$ & 5.9 & 0.5 & 6.68 & 0.30 & 98.87 & 890.2 \\
\hline
\end{tabular}

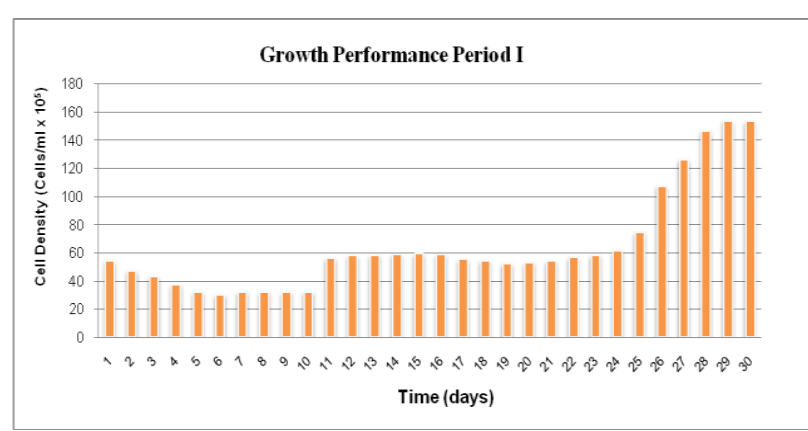

Fig. 1. Microalgal growth Chlorella sp in the first period giving $\mathrm{CO}_{2}$ emissions.

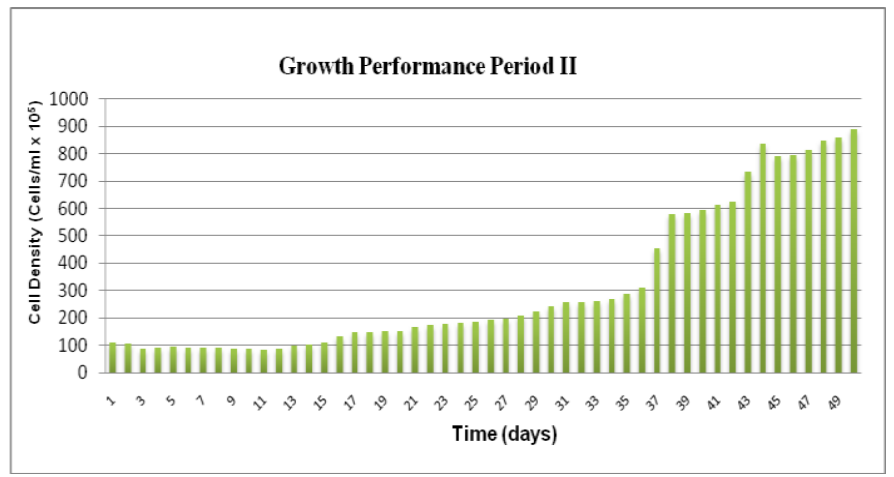

Fig. 2. Microalgal growth Chlorella sp in the second period giving $\mathrm{CO}_{2}$ emissions. 


\section{Environmental Conditions and the Relationship of $\mathrm{CO}_{2}$ Absorption}

Recording the results of the temperature around the pond culture at $27^{\circ} \mathrm{C}$ on a measurement was around 09.00 am and $34^{\circ} \mathrm{C}$ on the measurement around $15.00 \mathrm{pm}$. If the temperature increases, the humidity decreases, until the recorded minimum humidity was $45 \%$ while the maximum was $70 \%$. Microalgal growth was not seem affected by $\mathrm{pH}$ value and debit of $\mathrm{CO}_{2}$ fluctuations around the pond (Fig. 3), because it was still in the range appropriate for metabolic activities.

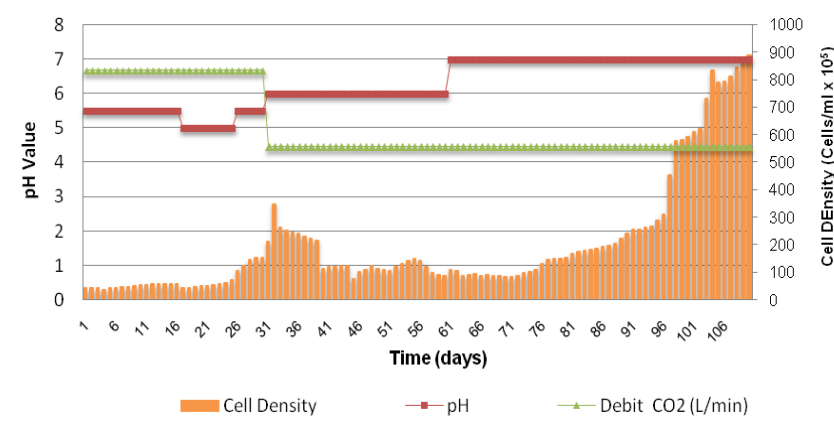

Fig. 3. Effect of $\mathrm{pH}$ value and Debit of $\mathrm{CO}_{2}(\mathrm{~L} / \mathrm{min})$ to microalgal growth (x $10^{5}$ cells $\left./ \mathrm{ml}\right)$.

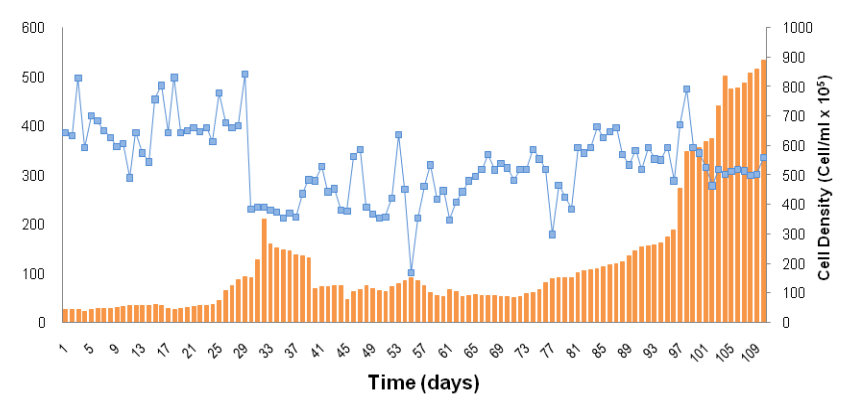

Cell Density (Cells/ml) $\rightarrow$ Light Intensity (10x) Lux

Fig. 4. Effect of light intensity to microalgal growth (x $10^{5}$ cells $\left./ \mathrm{ml}\right)$.

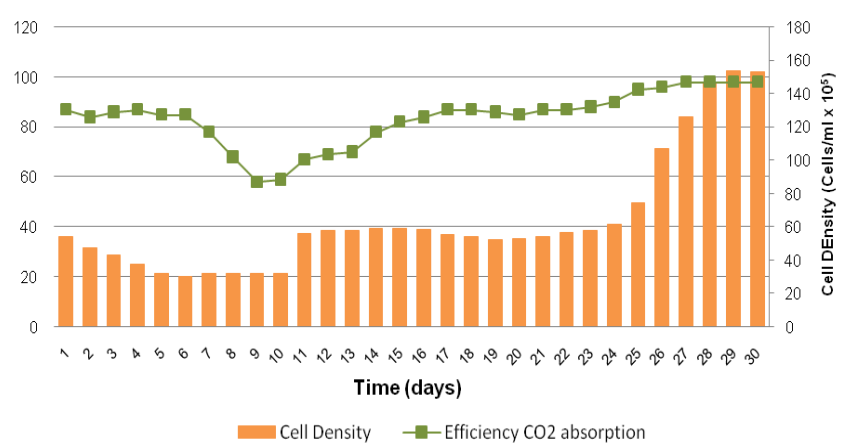

Fig. 5. The efficiency of $\mathrm{CO}_{2}$ absorption by microalgae.

Measurements showed that the light intensity at 09.00 am about 50,000 lux, at $15.00 \mathrm{pm}$ was reach 80,000 lux if sunny weather conditions. The range of light intensity was very good for the growth of microalgae (Fig. 4).

$\mathrm{CO}_{2}$ absorption by microalgae showed the range $89 \%$ to $100 \%$. High absorption occurs primarily in the sunny weather conditions and low absorption occurs in cloudy weather. Thus microalgae Chlorella sp. able to absorb $\mathrm{CO}_{2}$ up to $98.87 \%$ of $\mathrm{CO}_{2}$ absorption dynamics was not showed a decrease with increasing $\mathrm{CO}_{2}$ and microalgal growth tends to increase (Fig. 5).

Microalgae Chlorella sp. able to absorb $\mathrm{CO}_{2}$ at a concentration of $15-20 \%$ [12], [13]. In this study, the $\mathrm{CO}_{2}$ concentration used $5.2-5.9 \%$. Thus, there is still possibility of giving the $\mathrm{CO}_{2}$ concentration increased to $20 \%$. In a given gas composition with a concentration of $\mathrm{CO}$ gas contained more than $1000 \mathrm{ppm}$, but the growth of microalgae was not indicate a problem. The study uses microalgae for the absorption of the industrial $\mathrm{CO}_{2}$ emissions is mitigation impacts of air pollution [14]. The system was equipped with a culture pond heat exchangers demonstrated the ability to lower the temperature of the exhaust gas until it reaches a temperature that can be adapted by microalgae [15].

\section{CONCLUSION}

The addition of nutrients to the growth of microalgae are needed every 7 days and the addition of $\mathrm{P}$ is required every 14 days.

Based on the microalgal growth and graphic element content of anions in the media pond appears that the growth of microalgae culture greatly influenced by the availability of nutrients in pond culture media.

Microalgae Chlorella sp able to absorb 21-29\% concentration of $\mathrm{CO}_{2}$

The efficiency of $\mathrm{CO}_{2}$ absorption by microalgae Chlorella sp was $98.87 \%$ with $\mathrm{CO}_{2}$ giving an average of $160.32 \mathrm{~g} /$ day.

\section{ACKNOWLEDGMENT}

The authors would like to thank the management of PT. Indolakto, Cicurug, Sukabumi, West Java, Indonesia.

\section{REFERENCES}

[1] Meiviana. (2010). Environmental Factors. [Online]. Available: http://aatunhalu.wordpress.com

[2] L. Borges, B. M. Faria, C. Odebrecht, and P. C. Abreu, "Potencial de absorção de carbono por espécies de microalgas usadas na aquicultura: primeiros passos para o desenvolvimento de umMecanismo de desenvolvimento Limpo," Atlântica, Rio Grande, vol. 29, pp. 35-46, 2007.

[3] P. G. Falkowski and J. A. Raven, Aquatic Photosynthesis, Oxford, Blackwell Scientific Publishers, p. 374, 1997.

[4] Lalli and T. Parsons, Biological Oceanography: An Introduction, Oxford, Butterworth \& Heinemann Ltd., p. 301, 1993.

[5] S. A. Khan, Rashmi, M. Z. Hussain, S. Prasad, and U. C. Banerjee, "Prospects of biodiesel production from microalgae in India," Renewable and Sustainable Energy Reviews, vol. 13, pp. 2361-2372, 2009.

[6] M. A. Borowitzkz, "Pharmaceuticals and agrochemicals from microalgae," Chemicals from Microalgae, Taylor \& Francis, London, pp. 313-352, 1999.

[7] Y. Chisti, "Comparative evaluation of compact photobioreactors for large-scale monocultures of microalgae," J Biotechnol., vol. 70, pp. 231-247, 1999.

[8] C. E. M. Bicudo and M. Menezes, Gêneros de Algas Continentais do Brasil (Chave para identificação e descrições), RiMa, São Carlos, 2006.

[9] Technology. (2010). $\mathrm{CO}_{2}$-adsorbing Microalgae Cultivated Using Power Plant Gas Exhoust. [Online]. Available: http://www.japanfs.org/en/pages/029515.html

[10] Steenblok, "Carbon dioxide fixation heterotrophic products of Euglena," Plant Physiol., vol. 65, pp. 566-568, 2000.

[11] Dianursanti, R. A. Nuzulliany, and M. N. Wijanarko, "Improved biomass production of chlorella vulgaris by treatment trapping techniques in flow circulation cell culture media," Pros. National Seminar on Chemical Engineering Indonesia - SNTKI, Bandung, 2009.

[12] G. P. Jennifer and J. P. Meyrick, "Heterotrophic carbon dioxide fixation products of euglena," Plant Physiol., vol. 65, pp. 566-568, 1979. 
[13] Anonymous. (2010). CO $\mathrm{CO}_{2}$-absorbing Microalga Cultivated Using Power Plant Exhaust Gas. [Online]. Available: http://japans.org/en/pages/029515

[14] Kastiyowati. (2010). Beautiful. Impact and Air Pollution Prevention Efforts. [Online]. Available: http://buletinlitbang.dephan.go.id

[15] Kraus and Bejan, Heat Transfer Handbook, USA: John Wiley and Sons, 2003.

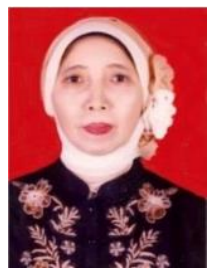

Titin Handayani was born in Central Java Indonesia on October $25^{\text {th }}, 1957$. She received the master and doctor degree in agronomic from Bogor Agriculture University, in 195 and 2003, respectively. She is currently a professor in the Institute for Environmental Technology, Agency for the Assessment and Application of Technology and has been the director of the laboratory of plant biotechnology since 2003. Her current research interest include tissue culture and molecular analysis on food crop and horticulture She published more than 100 scientific papers and book in the field of food crop and horticulturre production through conventional and non-conventional technology. 